\title{
The Role of Indefinite Detention in Antiterrorism Legislation*
}

There is considerably less to be proud about, and a good deal to be embarrassed about, when one reflects on the shabby treatment civil liberties have received in the United States during times of war and perceived threats to its national security.

For as adamant as my country has been about civil liberties during peacetime, it has a long history of failing to preserve civil liberties when it perceived its national security threatened.... After each perceived security crisis ended, the United States has remorsefully realized that the abrogation of civil liberties was unnecessary. But it has proven unable to prevent itself from repeating the error when the next crisis came along.

-William J. Brennan, Jr. ${ }^{1}$

\section{INTRODUCTION}

The repercussions of September 11, 2001 (9/11), were felt not only here in the United States, but also around the world. In the wake of the attacks, similarly sweeping antiterrorism laws were rushed through both the American and British legislatures with little debate. In the United States, a vague joint resolution of Congress allowed for the detention of both citizens and noncitizens captured abroad in combat zones without the ability to challenge their sentences. Likewise, in the United Kingdom, the Anti-Terrorism Crime and Security Act 2001 (ATCSA), until its revision last year, allowed for the indefinite detention of noncitizens certified as terror suspects by the Home Secretary. ${ }^{2}$ In both countries, the opportunity for judicial review of a suspect's detention was (and to some extent still is) limited or nonexistent.

\footnotetext{
* Richard Raimond. I would like to thank the staff and board of the Kansas Law Review for their assistance getting this Comment into shape, Mark Mosier for his invaluable comments and suggestions, and my wife, Ellen, for just being her.

1. William J. Brennan, Jr., The Quest To Develop a Jurisprudence of Civil Liberties in Times of Security Crises, 18 ISR. Y.B. HUM. RTS. 11, 11 (1988).

2. National security in the United Kingdom is the province of the Home Department. The Secretary of State for the Home Department more commonly is referred to as the Home Secretary.
} 
Since the laws passed, however, cases have arisen in both the United States and the United Kingdom in which the government detained people for more than two years only to release them without charge. In the United States, the Supreme Court's decision in Hamdi v. Rumsfeld ${ }^{3}$ prompted the government to release Yaser Esam Hamdi to Saudi Arabia without charge in October 2004. ${ }^{4}$ Later that same year, the British House of Lords ruled that the ATCSA's detention provisions were incompatible with Britain's commitments to the European Convention on Human Rights (ECHR), and the government announced that the provisions would be replaced. ${ }^{5}$ Since that ruling, however, the July 2005 bombings in London have prompted the introduction of a further set of terrorism laws. ${ }^{6}$

Although Hamdi and others eventually were released, their releases came only after months of detention - and future detainees may not fare as well. In both countries, cases involving the hastily assembled laws have found their way to the courts on a case-by-case basis, with little consensus between rulings as to how to apply the law. Despite fierce criticism, the U.S. government's policy in particular seems to be largely reactionary: making the minimum changes necessary as and when adverse court decisions are handed down, while still attempting to keep suspects detained indefinitely. ${ }^{7}$ This ad hoc approach is justified on grounds that both the Joint Resolution and the ATCSA were intended in large part as temporary measures for times of emergency only. Britain's previous experience with domestic terrorism belies its temporary nature, however, with a series of supposedly temporary antiterrorism provisions being extended indefinitely over a longer period of time. ${ }^{8}$ Even if there

3. 542 U.S. 507 (2004).

4. Eric Lichtblau, U.S., Bowing to Court, Will Free 'Enemy Combatant,' N.Y. TIMES, Sept. 23, 2004, at A1. The U.S. government has also released a number of other, lower-profile detainees. See, e.g., 38 Guantanamo Detainees to be Freed After Tribunals, FEDERAL DocUMENT CLEARING House CBS NEWSWIRE, March 30, 2005, available at 2005 WL 735527 (detailing the release of thirty-eight detainees found not to be "enemy combatants").

5. Vikram Dodd et al., Freed Britons Sent Home: Clarke Unveils House Arrest Plan for Terror Suspects, THE GUARDIAN (London), Jan. 27, 2005, at 1 (detailing the release of four Britons released from Guantanamo without charge).

6. Tony Blair, U.K. Prime Minister, Remarks at Downing Street Press Conference (Aug. 5, 2005) (transcript available at http://politics.guardian.co.uk/terrorism/story/0,,1543385,00.html).

7. See Dana Priest, Long-Term Plan Sought for Terror Suspects, WASH. Post, Jan. 2, 2005, at A1 ("The Pentagon and the CIA have asked the White House to decide on a more permanent approach for potentially lifetime detentions, including for hundreds of people now in military and CIA custody whom the government does not have enough evidence to charge in courts.").

8. See Sir David Williams, The United Kingdom's Response to International Terrorism, 13 IND. INT'L \& COMP. L. REV. 683, 687-89 (2003) (detailing the enactment and subsequent renewal of various British antiterrorism provisions). 
is a foreseeable end to the War on Terror, it may be a long time in coming, and to simply detain people for the duration will amount to a life sentence without trial. ${ }^{9}$

This Comment will argue for the need for revised antiterrorism legislation based on three main principles. First, any legislation should be designed as a permanent measure to recognize that the War on Terror is an ongoing situation, and that short-term gains in matters of national security need to be balanced against the ongoing erosion of civil rights. Second, the legislation needs to allow for the detainees to meaningfully challenge the grounds for their detentions before neutral decision makers. Finally, the legislation should not discriminate between detainees purely on the basis of nationality, and it should allow noncitizens the same opportunity to at least challenge their sentences as citizens, while conversely giving the government similar powers to use against citizen terrorists as against those who are noncitizens.

Part II of this Comment charts the United States' past experiences in dealing with rebels and enemy saboteurs operating outside the traditional rules of war, while still generally managing to maintain sight of the Constitution and the right to habeas relief. To demonstrate how underprepared, reactionary legislation has a tendency of becoming the norm, Part II also examines Britain's legislative attempts directed at domestic terrorism. Part II also examines more recent cases from both countries to show how detention without trial has been a very real problem in both the United States and United Kingdom.

Part III then evaluates present approaches before concluding that present legislation, both temporary in nature and cobbled together from existing law, is singularly unsuited to dealing with the problem of international terrorism. Part III then attempts to synthesize and expand on recent rulings to present an integrated and coherent approach to the capture and detention of terror suspects.

9. Even President Bush has stated that the War on Terror may not be winnable. Speaking on NBC's Today Show, Bush stated, "I don't think you can win it." Aides sought to contextualize Bush's statements by claiming that Bush was acknowledging that there would not be a conventional surrender or signing of treaties to signal an end to the war. Richard Benedetto, Democrats Leap on Terror War Remark, USA TODAY, Aug. 31, 2004, at 6A. 


\section{BACKGROUND}

\section{A. Emergency Powers of Detention in the United States Before 9/11}

The use of executive power to override customary civil liberties dates back to at least the Civil War. In 1861, Lincoln suspended habeas corpus, empowering himself to arrest "disloyal" citizens (i.e., Confederate sympathizers) without giving them access to the courts to challenge their detentions. ${ }^{10}$ At least one court held this presidential use of executive power unconstitutional, ${ }^{11}$ but Lincoln and the military, riding popular opinion, ignored the courts. ${ }^{12}$ Two years later, Congress authorized similar future suspensions of habeas corpus without directly legitimizing, but effectively condoning, Lincoln's previous proclamations. $^{13}$ When the war ended, the transition back to regular democracy was somewhat shaky. In 1864, an Indiana man was arrested for sedition and sentenced to death by a military tribunal. ${ }^{14}$ The Supreme Court heard his habeas petition and held that because the military commission was not a court vested with judicial power by Congress, it had no right to charge a civilian. ${ }^{15}$ The Court stated that the exigencies of wartime may justify the suspension of certain civil liberties but that they should be restored as soon as possible:

During the late wicked Rebellion, the temper of the times did not allow that calmness in deliberation and discussion so necessary to a correct conclusion of a purely judicial question. Then, considerations of safety were mingled with the exercise of power; and feelings and interests prevailed which are happily terminated. Now that the public safety is assured, this question, as well as all others, can be discussed and

10. Melissa K. Matthews, Restoring the Imperial Presidency: An Examination of President Bush's New Emergency Powers, 23 HAMLINE J. PUB. L. \& POL'Y 455, 465 (2002).

11. Id. (quoting Ex parte Merryman, 17 F. Cas. 144, 149 (C.C.D. Md. 1861) (No. 9,487) ("I can see no ground whatever for supposing that the President, in any emergency, or in any state of things, can authorize the suspension of the privilege of the writ of habeas corpus ....")). Notably, popular sentiment was against the Merryman decision, as reflected in an editorial from the New York Tribune, which stated that "[ $\mathrm{t}] \mathrm{he}$ Chief Justice takes sides with traitors." Brennan, supra note 1, at $13-14$.

12. See Matthews, supra note 10, at 466 (stating that Lincoln "blatantly ignored this ruling").

13. An Act relating to Habeas Corpus, and regulating Judicial Proceedings in Certain Cases, Ch. 81, 12 Stat. 755 (1863).

14. Ex parte Milligan, 71 U.S. 2, 6-7 (1866).

15. Id. at 40 . 
decided without passion or the admixture of any element not required to form a legal judgment. ${ }^{16}$

The Court's message was clear: it was willing to overlook executive suspension of habeas corpus during brief periods of national emergency, but should the government try to retain these powers past the end of the emergency, the courts would enforce the Constitution.

During the Second World War, the Supreme Court again upheld the executive's power to detain people charged with no wrongdoing on grounds of national emergency. More than 10,000 people of Japanese, German, and Italian ancestry were forced from their homes and sent to relocation centers along the West Coast. ${ }^{17}$ During this same period, the Court upheld the executive's decision to try German soldiers who had entered the country on a sabotage mission by closed military tribunal. ${ }^{18}$ The Court reaffirmed that Congress had acknowledged military commissions as courts of military law with jurisdiction over all military matters and held that the petitioners therefore had no right to a jury trial. ${ }^{19}$ It was also in this case that the Court first drew the distinction between lawful and unlawful combatants. ${ }^{20}$ This distinction would again be used by the Court in deciding the Guantanamo Bay cases. ${ }^{21}$ Only in one instance did the courts decline to hear detainees' habeas petitions entirely. Twenty-one German citizens, convicted of war crimes, were held in a U.S. prison in occupied Germany following the end of World War II. The Court declined to hear their petitions because they were not U.S. citizens, had never set foot on U.S. soil, were not detained in the United States, and had been tried and convicted by a military commission. ${ }^{22}$

16. Id. at 109 .

17. Danielle Tarin, Note, Will an Attack on America Justify an Attack on Americans? Congressional and Constitutional Prohibitions on the Executive's Power to Detain U.S. Citizens as Enemy Combatants, 44 VA. J. INT'L L. 1145, 1155 (2004). In Hirabayashi v. United States the Court sustained the conviction of an American citizen of Japanese ancestry for violation of a militarily imposed curfew. 320 U.S. 81 (1943). A year later, in Korematsu v. United States, the Court upheld an order preventing people of Japanese, Italian, or German ancestry from entering an "exclusion zone." 323 U.S. 214 (1944).

18. Ex parte Quirin, 317 U.S. 1 (1942).

19. Id. at $28-29$.

20. Id. at 31. "Lawful combatants are subject to capture and detention as prisoners of war by opposing military forces. Unlawful combatants are likewise subject to capture and detention, but in addition they are subject to trial and punishment by military tribunals for acts which render their belligerency unlawful." Id.

21. E.g., Hamdi v. Rumsfeld, 542 U.S. 507, 514-16 (2004).

22. Johnson v. Eisentrager, 339 U.S. 763, 777 (1950). The Court set out six criteria to be met 
More recently, following the 1995 Oklahoma City bombing, Congress enacted the Antiterrorism and Effective Death Penalty Act of 1996 (AEDPA). ${ }^{23}$ The AEDPA provided enhanced immigration procedures mandating the detention of aliens illegally present in the country who had been convicted of a felony. ${ }^{24}$ Prior to this act, the Immigration and Naturalization Service (INS) could exercise discretion in deciding whether to detain the alien pending deportation. ${ }^{25}$ Once detained under the act, the noncitizen's right to habeas was limited to a determination of whether the petitioner was an alien, and whether he could prove he had been legally admitted. ${ }^{26}$

\section{B. Developing Antiterrorism Law in the United States Since 9/11}

Since 9/11, a series of cases have made their way through the courts challenging the President's assertions that terrorists, as enemy combatants, can be detained indefinitely without any recourse to either the civilian or military courts. Courts generally have been split on how to balance on the one hand concerns of national security and deference to the President in his role as Commander in Chief, and on the other individual human rights - primarily the right to liberty. Reversals between the district and circuit courts have been frequent, as have splits between the circuits. The Supreme Court has decided several cases involving people detained under the Joint Resolution, but its decisions necessarily are limited to the cases before it, and even then its holdings are subject to further interpretation by the district courts on remand.

before such a detainee could be denied habeas relief. The detainee:

(a) is an enemy alien; (b) has never been or resided in the United States; (c) was captured outside of our territory and there held in military custody as a prisoner of war; (d) was tried and convicted by a Military Commission sitting outside the United States; (e) for offenses against laws of war committed outside the United States; (f) and is at all times imprisoned outside the United States.

Id.

23. Pub. L. No. 104-132, 110 Stat. 1214 (1996) (codified as amended in scattered sections of tit. 8 of the United States Code).

24. Id. § 439, 110 Stat. at 1276 (codified at 8 U.S.C. $\S 1252 \mathrm{c}(2003)$ ).

25. Dana Keith, In the Name of National Security or Insecurity?: The Potential Indefinite Detention of Noncitizen Certified Terrorists in the United States and the United Kingdom in the Aftermath of September 11, 2001, 16 FLA. J. INT'L L. 405, 421-22 (2004).

26. 8 U.S.C. $\S 1252(\mathrm{e})(2)(2003)$. 
1. The Authorization for the Use of Military Force and Detention Order

Within a week of 9/11, Congress passed a Joint Resolution granting the President the authority

to use all necessary and appropriate force against those nations, organizations, or persons he determines planned, authorized, committed, or aided the terrorist attacks that occurred on September 11, 2001, or harbored such organizations or persons, in order to prevent any future acts of international terrorism against the United States by such nations, organizations or persons. ${ }^{27}$

Shortly thereafter, pursuant to this Joint Resolution, the President issued an order authorizing the Secretary of Defense to detain anyone the President had "reason to believe" (1) was a member of Al Qaeda; (2) had engaged in, aided or abetted, or conspired to commit, acts of terrorism; or (3) knowingly harbored such a person. ${ }^{28}$

\section{Hamdi v. Rumsfeld}

In the weeks following the Joint Resolution, the President sent troops to Afghanistan to overthrow the Taliban regime that harbored Al Qaeda. ${ }^{29}$ The Northern Alliance, a coalition of anti-Taliban forces, seized Yaser Esam Hamdi, a U.S. citizen, ${ }^{30}$ and handed him over to the U.S. military. ${ }^{31}$ Hamdi initially was transferred to the American base at Guantanamo Bay in Cuba, but when the government learned of his citizenship he was transferred to a naval brig in Charleston, South Carolina. ${ }^{32}$ The government contended, under the standard established in Ex parte Quirin, ${ }^{33}$ that Hamdi was an "enemy combatant" and as such

27. Authorization for Use of Military Force, Pub. L. No. 107-40, 115 Stat. 224 (2001). This was the first time in American history that the use of force was explicitly authorized not just against other states, but also against "persons." Michael J. Glennon, Forging a Third Way to Fight: "Bush Doctrine" for Combating Terrorism Straddles Divide Between Crime and War, LEGAL TIMES, Sept. 24, 2001, at 68 .

28. Detention, Treatment, and Trial of Certain Non-Citizens in the War Against Terrorism, 66 Fed. Reg. 57,833, 57,834 (Nov. 16, 2001).

29. Hamdi v. Rumsfeld, 542 U.S. 507, 510 (2004).

30. Id. Hamdi was born in Louisiana, and thus was a U.S. citizen, although his family had moved to Saudi Arabia while Hamdi was still a child. Id.

31. Id.

32. Id.

33. See supra note 20 and accompanying text. 
could be held indefinitely without charge and without access to counsel. ${ }^{34}$

In June 2002, Hamdi's father filed a habeas petition on Hamdi's behalf, contending that, as a U.S. citizen, Hamdi's detention without access to counsel was illegal and in violation of the Fifth and Fourteenth Amendments. ${ }^{35}$ Hamdi's father contended that his son had been in Afghanistan doing relief work and that he had been in the country only for two months before 9/11, which would not have allowed him enough time to receive military training. ${ }^{36}$ The district court appointed counsel and ordered that he have access to Hamdi. ${ }^{37}$ On appeal, the Fourth Circuit reversed, holding the district court failed to defer adequately to the government's security and intelligence interests. ${ }^{38}$ The Fourth Circuit urged the district court to "consider the most cautious procedures first" " in conducting a suitably deferential review of Hamdi's status. ${ }^{39}$

On remand, the government presented a declaration from Michael Mobbs, a special advisor to the Under Secretary of Defense for Policy. ${ }^{40}$ Although he had never met Hamdi, Mobbs stated he was familiar with the military's detention procedures and had personally reviewed the records concerning Hamdi's capture and detention. ${ }^{41}$ Mobbs reiterated the government's evidence for Hamdi's detention. According to Mobbs, Hamdi had traveled in July or August 2001 to Afghanistan where he had received weapons training by the Taliban. ${ }^{42}$ Hamdi then fought against the Northern Alliance forces, to which he subsequently surrendered, turning over his assault rifle when he did so. ${ }^{43}$ When handed over to American troops, Hamdi allegedly admitted in interrogation that he had "entered Afghanistan the previous summer to train with and, if necessary, fight for the Taliban." 44 As a result, Hamdi was classified an enemy combatant. ${ }^{45}$

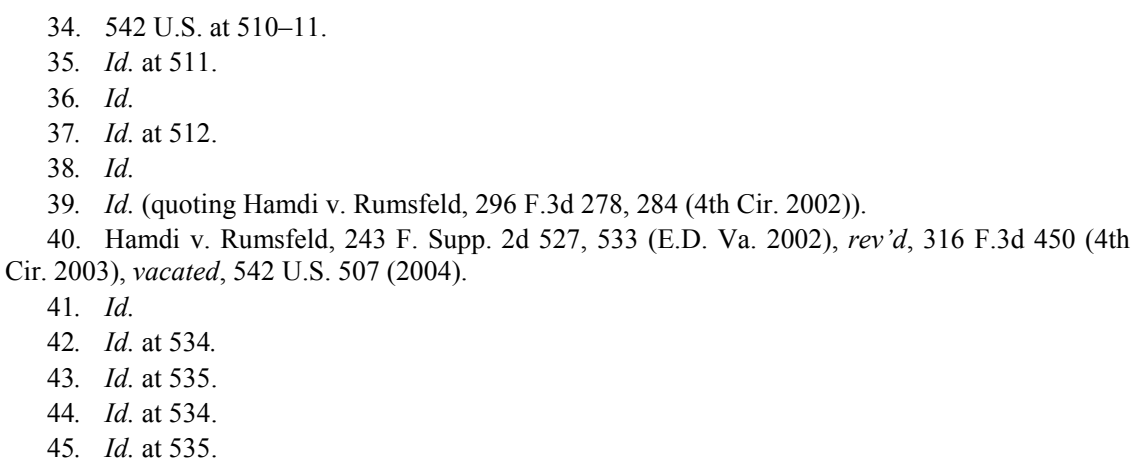


The district court found that Mobbs's declaration fell "far short of even [the] minimal criteria for judicial review." the vague, hearsay nature of the declaration and concluded that it led "to more questions than it answers." 47 The court ordered the government to turn over evidence of both the military's screening procedures and records of Hamdi's statements for in camera review so that a proper determination of the legality of Hamdi's detention could be made. ${ }^{48}$

The government appealed the production order and the district court certified the question of "whether the Mobbs Declaration, standing alone, is sufficient as a matter of law to allow a meaningful judicial review of [Hamdi's] classification as an enemy combatant." ${ }^{49}$ The Fourth Circuit again reversed, holding that:

[b]ecause it is undisputed that Hamdi was captured in a zone of active combat in a foreign theater of conflict ... the submitted declaration is a sufficient basis upon which to conclude that the Commander in Chief has constitutionally detained Hamdi pursuant to the war powers entrusted to him by the United States Constitution. No further factual inquiry is necessary or proper. ${ }^{50}$

The court further found that the Joint Resolution "necessarily include[d] the capture and detention of any and all hostile forces arrayed against our troops" thus giving the President explicit congressional authority to detain enemy combatants, including U.S. citizens. ${ }^{51}$ Finally, the court rejected Hamdi's argument that his status as an American citizen detained on American soil should affect the result. Relying on the fact that one of the defendants in Quirin was a naturalized citizen, the court stated that "[o]ne who takes up arms against the United States in a foreign theater of war, regardless of his citizenship, may properly be designated an enemy combatant and treated as such." ${ }^{\text {"52 The Supreme }}$ Court granted certiorari to hear Hamdi's case.

The Court began by determining the "threshold question... [of] whether the Executive has the authority to detain citizens who qualify as 'enemy combatants.",53 In this, the Court sided squarely with the Fourth

46. Id. at 533 .

47. Id.

48. Id. at $528-29$.

49. Hamdi v. Rumsfeld, 316 F.3d 450, 462 (4th Cir. 2003), vacated, 542 U.S. 507 (2004).

50. Id. at 459 .

51. Id. at 467. 18 U.S.C. $\S 4001$ (a) (2000) states, "[n]o citizen shall be imprisoned or otherwise detained by the United States except pursuant to an Act of Congress."

52. Hamdi, 316 F.3d at 475.

53. Hamdi v. Rumsfeld, 542 U.S. 507, 516 (2004). 
Circuit and held that in passing the Joint Resolution, "Congress has clearly and unmistakably authorized detention in the narrow circumstances considered here." ${ }^{54}$ The detention of enemy combatants, regardless of citizenship, was necessary "to prevent captured individuals from returning to the field of battle and taking up arms once again."

The Court expressed concern, however, at the potential length of Hamdi's detention. Whereas conventional wars tend to last a few years, the unconventional nature of the War on Terror could mean that it stretches on for several generations. ${ }^{56}$ As a result, "Hamdi's detention could last for the rest of his life." however, by noting that "[a]ctive combat operations against Taliban fighters ... are ongoing in Afghanistan" and, as such, "[t]he United States may detain, for the duration of these hostilities, individuals legitimately determined to be Taliban combatants who 'engaged in an armed conflict against the United States.", nature of Hamdi's detention would only become an issue following the outright defeat of the Taliban in Afghanistan.

Having established that the government was entitled to detain such enemy combatants for the duration of hostilities, the Court then moved to the issue of what review, if any, such detainees were entitled. The entire Court agreed that, "absent suspension, the writ of habeas corpus remains available to every individual detained within the United States." ${ }^{59}$ More importantly, all agreed that the writ had not been suspended. ${ }^{60}$ The government urged the Court to adopt the Fourth Circuit's ruling that, because Hamdi was seized in a combat zone, no further hearing or fact finding was necessary. ${ }^{61}$ The Court rejected this argument, noting that it could not be called "undisputed" where Hamdi had no real opportunity to contest his categorization as an enemy combatant. ${ }^{62}$

Relying on the Mathews v. Eldridge ${ }^{63}$ test, the Court attempted to balance Hamdi's "most elemental of liberty interests - the interest in being free from physical detention by one's own government" 64 against

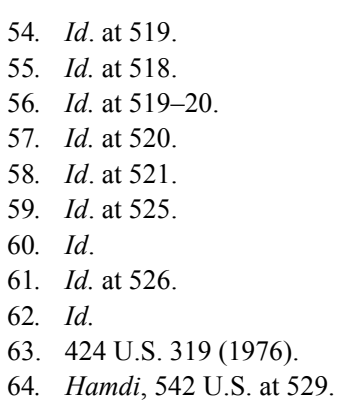


the "sensitive governmental interests in ensuring that those who have in fact fought with the enemy during a war do not return to battle against the United States." 65 Moreover, the Court took note of the government's argument that military officers engaged in waging war abroad could not be "dangerously distracted" by litigation occurring at home and that discovery into military secrets would "intrude on the sensitive secrets of national defense." 66

The Court found that neither the government's proposed solution nor that proposed by the district court struck the "proper constitutional balance" between the executive's security interests and Hamdi's personal interests. ${ }^{67}$ The Court held that "a citizen-detainee seeking to challenge his classification as an enemy combatant must receive notice of the factual basis for his classification, and a fair opportunity to rebut the government's factual assertions before a neutral decisionmaker." 68 This approach could still be tailored to allow flexibility to the government, however. The Court stated that the government may rely on hearsay evidence in such a hearing and that there would be a presumption in its favor, albeit a rebuttable one. ${ }^{69}$ Once the government had put forth "credible evidence" of the detainee's enemy combatant status, the burden would shift to the detainee to persuade with his own counter evidence. ${ }^{70}$

The Court found that Hamdi's treatment fell far short of this required standard of due process and that he was entitled to bring his evidence before a neutral decision maker, but left open the possibility that this standard could be met by "an appropriately authorized and properly constituted military tribunal.", " Military regulations already provided for such process in prisoner of war cases, and because Hamdi had been detained in a combat zone, the Court's earlier holding in Ex parte Milligan would not apply. ${ }^{72}$ Perhaps the Court's most stinging rebuke, however, was that "a state of war is not a blank check for the President when it comes to the rights of the Nation's citizens."73

Rather than give Hamdi a hearing, however, the government decided it would be easier to release him to Saudi Arabia-where he also held

65. Id. at 531 .

66. Id. at 532 .

67. Id.

68. Id. at 533 .

69. Id. 533-34.

70. Id. at 534.

71. Id. at 538 .

72. Id. at 521-22, 538. In Ex parte Milligan, 71 U.S. 2, 6-7 (1866), the Court held that a military commission did not have jurisdiction over a nonmilitary citizen.

73. Id. at 536 . 
citizenship - under certain conditions. ${ }^{74}$ The Justice Department claimed that the conditions of Hamdi's release ensured the safety of the United States, but the decision to release him was seen widely as a defeat to the government's assertions of its unlimited powers of detention during wartime. ${ }^{75}$ That the government was unable to build a case against Hamdi during the two years it detained him also casts doubt on the legitimacy of some of the other detainees' sentences.

\section{Rasul v. Bush}

At the same time as the Court was deciding the rights of an alleged American citizen turned enemy combatant in Hamdi, it also was considering the rights of the noncitizens captured in Afghanistan and detained without charge at Guantanamo. ${ }^{76}$ In 2002, the petitioners filed various actions in district court challenging the legality of their detentions. ${ }^{77}$ Construing all the actions as habeas applications, the district court relied on Johnson v. Eisentrager ${ }^{78}$ and dismissed them. In doing so it affirmed the government's argument that "aliens detained outside the sovereign territory of the United States [may not] invok[e] a petition for a writ of habeas corpus." continue to be held indefinitely without charge and without access to the courts to challenge their sentences, so long as they were detained outside the United States. The court of appeals affirmed. ${ }^{80}$

The Supreme Court started from the premise that "Congress has granted federal district courts ... the authority to hear applications for habeas corpus by any person who claims to be held in custody in violation of the Constitution or laws or treaties of the United States.",81 Citizenship was not a statutory requirement. "“[A]t its historical core,", the Court added, "'the writ of habeas corpus has served as a means of

74. Lichtblau, supra note 4. The government required Hamdi to renounce his American citizenship, imposed restrictions upon his travel within Saudi Arabia, and required him to report suspected terrorist activity, such as if someone tried to recruit him. Id.

75. Id.

76. See Rasul v. Bush, 542 U.S. 466 (2004).

77. Id. at 471 .

78. 339 U.S. 763 (1950). See also supra note 22 and accompanying text.

79. Rasul v. Bush, 215 F. Supp. 2d 55, 68 (D.D.C. 2002), aff'd sub nom. Al Odah v. United States, 321 F.3d 1134 (D.C. Cir. 2003), rev'd sub nom. Rasul v. Bush, 542 U.S. 466.

80. Al Odah, 321 F.3d at 1144 .

81. Rasul, 542 U.S. at 473 (quoting 28 U.S.C. § 2241(a), (c)(3) (2000)). 
reviewing the legality of Executive detention, and it is in that context that its protections have been strongest." $" 82$

Although the government argued that Eisentrager should control, the Court distinguished the present case in several important respects:

They are not nationals of countries at war with the United States ...; they have never been afforded access to any tribunal, much less charged with and convicted of wrongdoing; and for more than two years they have been imprisoned in territory over which the United States exercises exclusive jurisdiction and control. ${ }^{83}$

Though not located in the United States, "[b]y the express terms of its agreements with Cuba, the United States exercises 'complete jurisdiction and control' over the Guantanamo Bay Naval Base, and may continue to exercise such control permanently if it so chooses." ${ }^{84}$ Noncitizen detainees at Guantanamo "no less than American citizens," were entitled to bring their habeas petitions in federal court and challenge the basis for their indefinite detentions. ${ }^{85}$

Unlike Hamdi, however, the government has chosen to release few foreigners, and the petitioners remain in indefinite detention while they attempt to bring their petitions in federal court. This is proving more difficult than the Court's ruling in Rasul would suggest, and the Court may again hear the issues initially raised in Rasul. In one subsequent district court ruling, the judge held that the noncitizen Guantanamo detainees were not entitled to habeas relief, drawing the distinction between the petitioner's ability to seek a writ of habeas in federal court, and his ability to obtain one. ${ }^{86}$ Less than two weeks later, another district court held that the Fifth Amendment applied to the Guantanamo detainees and that the government's detention of them violated their due process rights. ${ }^{87}$ The government also is considering other methods of circumventing Rasul by transferring noncitizen detainees to prisons built and monitored by the United States in their countries of citizenship, ostensibly under the control of those nations. ${ }^{88}$

\footnotetext{
82. Id. at 474 (quoting INS v. St. Cyr, 533 U.S. 289, 301 (2001)).

83. Id. at 467 .

84. Id. at 467-68 (citation omitted).

85. Id. at 481 .

86. Khalid v. Bush, 355 F. Supp. 2d 311, 323 (D.D.C. 2005) ("[I]n its own words, the Supreme Court chose to only answer the question of jurisdiction, and not the question of whether these same individuals possess any substantive rights on the merits of their claims.").

87. In re Guantanamo Detainee Cases, 355 F. Supp. 2d 443, 481 (D.C. Cir. 2005).

88. Priest, supra note 7.
} 


\section{Rumsfeld v. Padilla}

Unlike Hamdi and the petitioners in Rasul, Jose Padilla was not captured in Afghanistan, but instead was arrested in 2002 in Chicago on a material-witness warrant in connection with the 9/11 attacks. ${ }^{89}$ Padilla initially appeared before a New York district court and was appointed counsel. $^{90}$ Shortly thereafter, the President designated Padilla an enemy combatant because he was suspected of both being an Al Qaeda associate and trying to create a radiological dispersal device (commonly known as a "dirty bomb"). ${ }^{91}$ Padilla was transferred to a Navy brig in South Carolina and held in solitary confinement without charge and without access to a lawyer. ${ }^{92}$ The lawyer appointed to represent him on the material-witness warrant filed a habeas petition on his behalf in New York, and the case was brought before the district court. ${ }^{93}$

The district court held both that the President had the authority to designate a U.S. citizen captured on U.S. soil an enemy combatant and that, so designated, the detainee could be held for the duration of the conflict with Al Qaeda. ${ }^{94}$ The indefinite length of the detention again did not trouble the court: "So long as American troops remain on the ground in Afghanistan and Pakistan in combat with and pursuit of al Qaeda fighters, there is no basis for contradicting the President's repeated assertions that the conflict has not ended." $" 95$

The government did not try to argue, however, that Padilla had no right to a habeas petition. ${ }^{96}$ Instead it argued that "affording [Padilla] access to counsel would 'jeopardize the two core purposes of detaining enemy combatants - gathering intelligence about the enemy, and preventing the detainee from aiding in any further attacks against America."'97 The court allowed Padilla's lawyer to present the habeas

89. Padilla ex rel. Newman v. Bush, 233 F. Supp. 2d 564, $568-67$ (S.D.N.Y. 2002), aff'd in part, rev'd in part sub nom. Padilla v. Rumsfeld, 352 F.3d 695 (2d Cir. 2003), rev'd, 542 U.S. 426 (2004).

90. Id. at 571.

91. Id.

92. Id. at 569,574 .

93. Id. at 571 .

94. Id. at 588 .

95. Id. at 590. To counter the argument that the indefinite nature of the detention made it the equivalent of a criminal sentence, the court analogized to Kansas v. Hendricks, 521 U.S. 346 (1997), in which the Supreme Court upheld Kansas's Sexually Violent Predator Act, which provided for civil commitment as a preventative measure for those likely to commit such acts. Padilla, $233 \mathrm{~F}$. Supp. 2d at 591.

96. Padilla, 233 F. Supp. $2 d$ at 594.

97. Id. at 603. 
petition, and it held that Padilla should be allowed access to counsel for this limited purpose. ${ }^{98}$

On appeal, however, the Second Circuit found that "the President lacks inherent constitutional authority as Commander-in-Chief to detain American citizens on American soil outside a zone of combat." 99 Moreover, Congress's Joint Resolution did not provide the statutory authority necessary under 18 U.S.C. $\S 4001(a):{ }^{100}$

While it may be possible to infer a power of detention from the Joint Resolution in the battlefield context where detentions are necessary to carry out the war, there is no reason to suspect from the language of the Joint Resolution that Congress believed it would be authorizing the detention of an American citizen already held in a federal correctional institution and not 'arrayed against our troops' in the field of battle. ${ }^{101}$

The court remanded with instructions to the district court to issue a habeas writ giving the government thirty days to release Padilla, unless it chose to transfer him to a civilian facility and bring criminal charges. ${ }^{102}$

The government appealed to the Supreme Court, which granted certiorari, and the case was heard on the same day as Hamdi. Although the Court sternly rebuked the government in Hamdi for trying to use a state of war as a "blank check," Padilla's case swiftly was dismissed on procedural grounds, and the case was not heard on the merits. The district and appeals court both had concluded that Donald Rumsfeld, the Secretary of Defense, was the proper recipient of the habeas petition, and that, as such, New York's long-arm statute gave the courts jurisdiction over him. ${ }^{103}$ The Supreme Court reversed, however, holding that under the "immediate-custodian rule" the commander of the naval brig where Padilla was held was the proper recipient of the petition, and, as such, it should have been filed in South Carolina. ${ }^{104}$ The case was dismissed without prejudice, and Padilla again filed his habeas petition while remaining in detention.

98. Id. The court further noted that "there is no reason that military personnel cannot monitor Padilla's contacts with counsel, so long as those who participate in the monitoring are insulated from any activity in connection with this petition, or in connection with a future criminal prosecution." Id. at 604 .

99. Padilla v. Rumsfeld, 352 F.3d 695, 712 (2d Cir. 2003), rev'd, 542 U.S. 426 (2004).

100. See supra note 51 (listing relevant provision of 18 U.S.C. $\S 4001$ (a) (2000)).

101. 352 F.3d at 723 .

102. Id. at 724 .

103. Rumsfeld v. Padilla, 542 U.S. 426, 433 (2004).

104. Id. at 446 . 
The district court heard Padilla's correctly filed habeas petition in February 2005. ${ }^{105}$ Although the government tried to analogize Padilla's capture to Hamdi's, the court stated that any attempt to compare the two was like trying to compare "apples and oranges."106 While Hamdi's detention arguably was necessary to prevent him from returning to the battlefield, Padilla already was being held on a material-witness warrant and presented no further threat to the United States. ${ }^{107}$ As such, his reclassification as an enemy combatant and removal from the regular criminal justice scheme was "neither necessary nor appropriate." 108 The court further listed a number of crimes with which the government could charge Padilla instead of holding him as an enemy combatant. ${ }^{109}$ Finding no grounds for Padilla's continued detention, the court ordered the government to release Padilla within forty-five days. ${ }^{110}$

The Fourth Circuit found that Hamdi controlled and reversed, holding that the AUMF gave the President sufficient power to detain Padilla. ${ }^{111}$ Moreover, Padilla could likewise continue to be detained until the end of "the conflict with Al Qaeda in Afghanistan." "112 Before the Supreme Court could hear the case again, however, the government chose to criminally indict Padilla on charges of supporting terrorism and Padilla was transferred back into the Justice Department's custody to await trial. $^{113}$

\footnotetext{
105. Padilla v. Hanft, 389 F. Supp. 2 d 678 (D.S.C. 2005), rev'd, 423 F.3d 386 (4th Cir. 2005).

106. Id. at 685 (quoting Hamdi v. Rumsfeld, 337 F.3d 335, 344 (4th Cir. 2003) (Wilkinson, J., concurring)).

107. Id. at 686 .

108. Id

109. Id. at 691 .

110. Id. at 692 .

111. Padilla v. Hanft, 423 F.3d 386, 391 (4th Cir. 2005) (“As the AUMF authorized Hamdi's detention by the President, so also does it authorize Padilla's detention. Under the facts as presented here, Padilla unquestionably qualifies as an 'enemy combatant' as that term was defined for purposes of the controlling opinion in Hamdi.").

112. Id. at 392 .

113. Eric Lichtblau, In Legal Shift, U.S. Charges Detainee in Terrorism Case, N.Y. TIMES, Nov. 23,2005 , at $\mathrm{A} 5$.
} 


\section{Emergency Powers of Detention in the United Kingdom Before 9/11.}

\section{Britain's Relation to Northern Ireland and the "Troubles": An} Overview $^{114}$

To understand Britain's experience of domestic terrorism, which is concerned largely with the Irish Republican Army (IRA), it is helpful first to examine briefly the history of Britain's involvement in Northern Ireland. For a substantial period of history, successive British monarchs have laid claim to Ireland, starting with Henry II's invasion of Ireland in $1170 .{ }^{115}$ To increase control over the island, successive monarchs granted plantations of land to the British nobility. ${ }^{116}$ Following Henry VIII's formation of the Church of England, the imported landowners brought Protestantism to Ireland, clashing with the native Catholics and adding a dose of religious hatred to the already volatile cultural situation. ${ }^{117}$ Uprisings were frequent. ${ }^{118}$

In 1801, an Act of Union was formed abolishing the Irish government and instituting direct rule from Britain. ${ }^{119}$ In 1916, an attempt by the Irish to throw off British rule, known as the "Easter Rising," was met with savage reprisals and the uprising's leaders were executed. ${ }^{120}$ The resulting War of Independence between British troops and the IRA lasted until a treaty in 1920 partitioned the island in an attempt to restore peace. ${ }^{121}$ The treaty split the island into the larger, independent Catholic Republic of Ireland in the South, and the Protestant North, which remained part of the United Kingdom. The separation remains to date. ${ }^{122}$

The split was far from a happy one, however. Although the Protestant majority in the North desired to be part of Britain, the Catholic minority wanted to unite with the independent South. Hatred continued to foment, leading to the reforming of the Provisional IRA toward the

114. For a more detailed overview of the history of Northern Ireland, see CAIN Web service at http://cain.ulst.ac.uk/index.html.

115. John Darby, Conflict in Northern Ireland: A Background Essay, in FACETS OF THE CONFLICT IN NORTHERN IRELAND 15, 15 (Seamus Dunn ed., 1995).

116. Id. at $15-16$.

117. Id. at 16 .

118. Id.

119. Id.

120. Id. at $16-17$.

121. Id. at 17 .

122. Id. See also Partition and the Birth of Northern Ireland, http://www.bbc.co.uk/history/ war/troubles/origins/partition.shtml (last visited Nov. 11, 2005) (further detailing the history of the divide). 
end of the 1960s and a campaign of violence against the British Army in Northern Ireland. ${ }^{123}$ The violence soon spread to the British mainland, and between 1968 and 1998, more than 3000 people died as a direct result of terrorism. ${ }^{124}$ Pursuant to a tentative ceasefire, the Good Friday Agreement of 1998 brought the Catholic Unionists and the Protestant Loyalists together in an uneasy power-sharing agreement. ${ }^{125}$ By 2002, the cordiality had broken down and direct rule was reimposed from London. ${ }^{126}$

\section{Emergency Powers of Detention in Northern Ireland and Britain}

In response to the ongoing violence in Ireland, the British Parliament enacted a series of temporary measures, in effect creating a dual-track criminal justice system with differing standards for terror suspects and "Ordinary Decent Criminals," colloquially referred to as ODCs. ${ }^{127}$ The Detention of Terrorists Order of 1972 permitted anyone "suspected of having been concerned in the commission or attempted commission of any act of terrorism" to be detained for up to twenty-eight days. ${ }^{128}$ Under the regular criminal law, a suspect could be held for ninety-six hours at most. ${ }^{129}$ The 1972 order was supplemented the following year by the Northern Ireland (Emergency Provisions) Act 1973 (NIA). It allowed for the establishment of so-called "Diplock" Courts in which terror suspects could be tried by a single judge, sitting alone under less stringent rules of evidence. ${ }^{130}$

The foremost piece of antiterrorism legislation enacted in Britain during the next twenty years, however, was the Prevention of Terrorism (Temporary Provisions) Act 1974 (PTA). Although (as its name suggests) the Act was intended to be temporary in nature and was enacted to deal with a state of emergency, it was renewed annually without any real debate and even extended three times. ${ }^{131}$ The PTA was

\footnotetext{
123. Darby, supra note 115 , at $17-18$.

124. Williams, supra note 8 , at 689 .

125. John Darby, Northern Ireland: The Background to the Peace Process (2003), http://cain.ulst. ac.uk/events/peace/darby03.htm\#agreement.

126. Id.

127. Paddy Hillyard, Suspect Community: People's Experience of the PreVention of TERRORISM ACTS IN BRITAIN 4 (1993).

128. Jeremie J. Wattellier, Comparative Legal Responses to Terrorism: Lessons from Europe, 27 HASTINGS INT'L \& COMP. L. REV. 397, 407 (2004) (citing Detention of Terrorists (Northern Ireland) Order, Statutory Instrument (Northern Ireland 15) No. 1632, art. 4(1) (1972)).

129. HiLlyARD, supra note 127 , at 74 .

130. Keith, supra note 25, at 427.

131. HillyarD, supra note 127, at 4. The PTA was updated in 1976, 1984, and 1989. As well
} 
based on the earlier Prevention of Violence (Temporary Provisions) Act 1939 and the NIA, and extended the antiterrorism powers to the British mainland. The Act gave the Royal Ulster Constabulary (RUC) the power to conduct warrantless arrests or searches and seizures in terrorism cases without even reasonable suspicion. ${ }^{132}$ After twenty-four hours, if reasonable suspicion had not been developed the police had to release the suspect. ${ }^{133}$ If reasonable suspicion had developed, the RUC could hold the suspect for a further twenty-four hours after which time it had to charge or release him. ${ }^{134}$ This forty-eight-hour period before the suspect had to be charged could be further extended to a maximum of seven days, however, with the approval of the Home Secretary. ${ }^{135}$ At no time during these seven days did the detainee have access to a neutral magistrate, and the detainee's right to contact a solicitor or relative could be delayed indefinitely. ${ }^{136}$ Moreover, there was nothing to prevent the suspect from being re-arrested again concerning the same matter once the detention had ended. ${ }^{137}$ The process generally was used for information gathering, and of the 7052 people detained under the PTA between 1974 and 1991, 6097 of them were released without charge. ${ }^{138}$

At roughly the same time, before direct rule was reimposed from Britain, the Northern Irish Parliament introduced the hugely unpopular measure of internment. ${ }^{139}$ Suspected IRA leaders were rounded up and detained without charge. ${ }^{140}$ Internment widely was seen as promoting more political unrest than it solved, and the practice ultimately was abandoned in $1980 .^{141}$

The final piece of antiterrorism legislation introduced to Britain before 9/11, was the supposedly definitive Terrorism Act 2000. Many believed that by passing the Act the British Government was bowing to the inevitability of an ongoing problem with terrorism and that unlike the

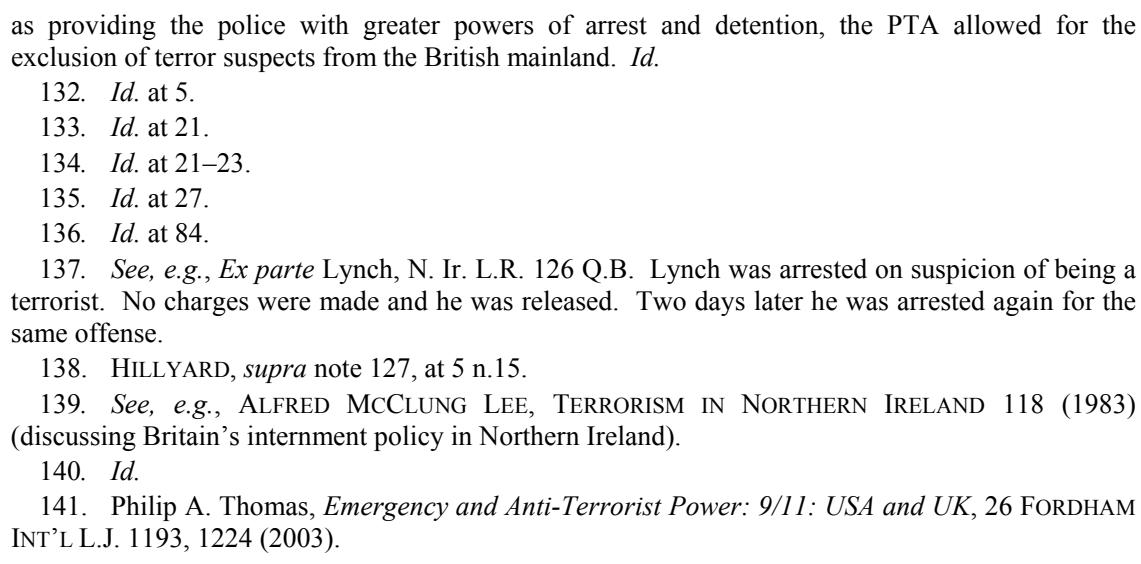


earlier PTA and EPA, the Terrorism Act 2000 was intended to be semipermanent. ${ }^{142}$ Unlike earlier legislation, it did not require annual parliamentary review, and it was streamlined to be the sole responsibility of the Home Secretary. ${ }^{143}$ The Act compiled and extended the police's existing powers and specifically related them to the specter of international terrorism, rather than just the narrower scope of domestic terrorism. $^{144}$

\section{Developing Antiterrorism Law in the United Kingdom Since 9/11}

\section{The ATCSA}

Although not the target of $9 / 11$ and with the ink barely dry on the supposedly definitive Terrorism Act 2000, the United Kingdom reacted to the attacks with its own harsher, new antiterrorism legislation. ${ }^{145}$ The ATCSA gave the government far-reaching powers of detention similar to those established in the United States even though the United Kingdom was not involved in military action abroad and despite criticism by some British judges and members of Parliament of the treatment of prisoners at Guantanamo Bay. ${ }^{146}$ The scope of the U.K. legislation may have been narrower than the U.S. legislation - the danger of indefinite detention extended only to noncitizens who could not be deported under Article 3 of the ECHR, because of the possibility that they would be tortured upon $\operatorname{arrival}^{147}$ - but, for those affected, the threat was a very real one.

Section 23 of the ATCSA allowed for the detention of a "suspected international terrorist... despite the fact that his removal or departure from the United Kingdom is prevented (whether temporarily or indefinitely)." 148 Certification as a terror suspect under the ATCSA is based entirely upon the reasonable suspicion of the Home Secretary. ${ }^{149}$ The definition of "terrorist" is disconcertingly broad. A terrorist is defined as, inter alia, someone who "has links with an international

\footnotetext{
142. Keith, supra note 25, at 431-32.

143. Id.

144. Id.

145. Williams, supra note 8, at 693.

146. Clare Dyer, Law Lord Castigates U.S. Justice: Guantanamo Bay Detainees Facing Trial by Kangaroo Court, THE GuARDIAN (London), Nov. 26, 2003, at 9 (describing Lord Steyn's branding of Guantanamo Bay as "a monstrous failure of justice").

147. Thomas, supra note 141, at 1218.

148. Anti-Terrorism, Crime and Security Act, 2001, c. 24, § 23 (Eng.), available at http://www. opsi.gov.UK/acts/acts2001/20010024.htm.

149. Id. $\S 21(1)$.
} 
terrorist group," and "ha[ving] links with" an international terrorist group is further defined as "support[ing] or assist[ing]" it. ${ }^{150}$

To enact the ATCSA, Britain was required to derogate from Article 5 of the ECHR. ${ }^{151}$ Although Article 5 allows signatory countries to detain "a person to prevent his effecting an unauthorised entry into the country or of a person against whom action is being taken with a view to deportation or extradition," 152 it does not allow for the indefinite detention of one against whom deportation action is being taken. Article 15 of the ECHR, however, allows member countries to derogate from most articles "[i]n time of war or other public emergency threatening the life of the nation." 153 Even then, the government can only take such action as is consistent with "the extent strictly required by the exigencies of the situation." 154 The European Court on Human Rights in the past has ruled in Britain's favor on such issues, but only in cases involving actual terrorist campaigns against the United Kingdom. ${ }^{155}$ By derogating from Article 5, Britain believed it could hold the detainees for as long as it took to deport them - in real terms, this meant indefinitely.

The ATCSA contains procedural safeguards to limit the possibility of civil rights abuses, but these lack any real bite. According to the thenHome Secretary, "[t]he detainees are free to leave the UK at any timethey can go home or to any third country that will accept them."156 Although this may sound reasonable, other countries generally have shown reluctance to accept an individual the United Kingdom has certified as a terrorist, and as of January 2004, only two suspects were released to other countries. ${ }^{157}$ Realistically, the detainees' only option was to appeal their certifications. Following certification by the

150. §21(2), (4).

151. Id. $\S 30$.

152. Convention for the Protection of Human Rights and Fundamental Freedoms, art. 5(1)(f), Nov. 4, 1950, 213 U.N.T.S. 221.

153. Art. 15(1). Article 15(2) states that Articles 2 (right to life), 3 (freedom from torture), 4(1) (freedom from slavery or servitude), and (7) (a person cannot be convicted of something that was not a criminal offense at the time of commission) may not be derogated from.

154. Art. 15(1).

155. See, e.g., Ireland v. United Kingdom, 2 Eur. H.R. Rep. 25 (1978) (declaring the United Kingdom was justified in derogating from Article 15 to hold Irish terror suspects for longer than allowed under Article 5); Lawless v. Ireland, 1 Eur. H.R. Rep. 15, 34 (1961) (declaring the Irish Government was "justified in declaring that there was a public emergency in the Republic of Ireland threatening the life of the nation and were hence entitled, applying the provisions of Article 15(1) ... to take measures derogating from their obligations under the Convention" to detain terrorism suspects without trial after the failure of the ordinary criminal law to contain the problem).

156. Press Release, Home Office, Special Immigration Appeals Comm'n Determination (Jan. 27, 2004), available at $\mathrm{http}: / / \mathrm{www} \cdot h o m e o f f i c e . g o v \cdot u k / n \_s t o r y . a s p ? i t e m \_\mathrm{id}=787$.

157. Id. 
Secretary of State, detainees had three months to appeal to the Special Immigration Appeals Commission (SIAC). ${ }^{158}$ Failing appeal, the SIAC had to review the certification as soon as reasonably possible after six months, and every three months thereafter. ${ }^{159}$ If the SIAC determined there was "no reasonable grounds" for suspecting the detainee of terrorism, they had to release him. ${ }^{160}$ The SIAC, however, sits in secret and the detainee could not appear before it in person. ${ }^{161}$ Instead, a "security-cleared special advocate" argued the case. ${ }^{162}$ Moreover, the Government could produce evidence without the detainee or his counsel even seeing it. ${ }^{163}$ For the most part, the SIAC generally showed great deference to the Home Secretary's certification, and it dismissed almost every appeal by detainees. ${ }^{164}$

\section{The cases of "M" and "G"}

The possibility that the certification and detention process could go wrong, however, first surfaced in several cases in which the SIAC determined there was insufficient evidence to justify the detention. One detainee, identified only as $\mathrm{M}$, was released without charge after sixteen months in Britain's notorious Belmarsh prison. ${ }^{165}$ In harsh terms, the SIAC concluded that M was convicted on "unreliable" evidence, and that the Secretary of State had "exaggerated" his links to Al Qaeda. ${ }^{166} \mathrm{M}$ claimed that he was not told of the reason for his detention until seven months after he was arrested and that none of the detainees had even been questioned by the intelligence services since being jailed. ${ }^{167}$ Not long after this, another detainee identified as $G$ was released to house

158. Anti-Terrorism, Crime and Security Act, 2001, c. 24, § 25 (Eng.), available at http://www. opsi.gov.uk/acts/acts2001/20010024.htm.

159. Id. § 26 .

160. Id.

161. Thomas, supra note 141, at 1218-19.

162. Id.

163. Id.

164. See, e.g., A v. Sec'y of State for Home Dep't, [2004] EWCA (Civ) 1123 [1] (Eng.) (dismissing the appeals of ten detainees certified as terror suspects and ruling that they should stay in prison and similarly refusing an appeal to dismiss the certification of two detainees who had been released to other countries).

165. Audrey Gillan, For Detainee M, Still no Explanation Why He Was Locked Up for 16 Months: Terror Suspect Held Without Trial Feared He Would Stay in Prison Until He Died, THE GUARDiAN (London), Apr. 23, 2004, at 4.

166. Id.

167. Id. 
arrest after becoming mentally ill because of the conditions of his detention. ${ }^{168}$

\section{A v. Secretary of State for the Home Department}

The most striking blow to the British government's detention procedures came in December 2004 with the House of Lords' ruling on the appeals of the remaining detainees. The appellants, foreign nationals of various countries, had been certified and detained under the ATCSA at the same time as G and M. ${ }^{169}$ They duly appealed their certification to the SIAC, which affirmed the certification. ${ }^{170}$ On appeal, the court considered each detainee individually and affirmed all the certifications, finding that, in each instance, the Home Secretary had reasonable suspicion for certifying the individual. ${ }^{171}$ On the issue of whether Britain's derogation from the ECHR was valid, the court also upheld the government's position that a present emergency existed: "The threat to the nation, which underlies the derogation, is posed by any of the various activities of Al Qa'eda and those who are associated with it." ${ }^{172}$ The detainees' appeals were dismissed. ${ }^{173}$

The detainees appealed to the House of Lords on the sole issue of whether Britain's derogation from the ECHR was valid. ${ }^{174}$ The Lords considered the appeal in two stages: they asked first whether there was a valid "public emergency threatening the life of the nation within the meaning of Article 15(1)" and second whether the derogation was consistent with the extent "strictly required by the exigencies of the situation." " The Lords found it "puzzling" that Britain was "the only country to have found it necessary to derogate" from the ECHR when it was "clear that other countries face considerable threats from terrorists within their borders," but were willing to show deference to the government in making such a decision. ${ }^{176}$ The judgment required

\footnotetext{
168. Audrey Gillan, Release of Terrorist Shocks Blunkett: Home Secretary Vows to Change Law Over House Arrest for Algerian, THE GUARDIAN (London), Apr. 24, 2004, at 8.

169. A v. Sec'y of State of Home Dep't, [2004] UKHL (Civ) 56, [2], 2005 All E.R. 169 (Eng.).

170. A v. Sec'y of State of Home Dep't, [2004] EWCA (Civ) 1123, 2004 All E.R. 62 (A.C.) (Eng.).

171. Id. [174]-[207]. Lord Justice Laws even went so far as to state of one detainee, "[w]e regard D as a practised and accomplished liar." Id. [204].

172. Id. [219].

173. Id. [151].

174. A v. Sec'y of State for the Home Dep't, [2004] UKHL (Civ) 56, [2], 2005 All E.R. 169 (Eng.).

175. Id. [16], [30].

176. Id. [23].
} 
"making a factual prediction of what various people around the world might or might not do, and when (if at all) they might do it, and what the consequences might be if they did." ${ }^{\prime 17}$ As such, the Home Secretary was in a better position to make such a judgment, and "[i]t would have been irresponsible not to err, if at all, on the side of safety."

On the issue of proportionality, however, the Lords held against the government, citing three main concerns with the detention provisions of the ATCSA:

(a) [they] did not address the threat presented by UK nationals, (b) [they] permitted foreign nationals suspected of being Al-Qa'ida terrorists or their supporters to pursue their activities abroad if there was any country to which they were able to go, and (c) the sections permitted the certification and detention of persons who were not suspected of presenting any threat to the security of the United Kingdom as Al-Qa'ida terrorists or supporters.

Given that the SIAC had heard evidence of "upwards of a thousand individuals from the UK... [who] attended training camps in Afghanistan in the last five years" the terrorist threat could hardly be said to come only from foreign nationals, the sole subject of the derogation order. ${ }^{180}$ As such, the derogation was discriminatory.

Moreover, the provision allowing detainees to voluntarily leave for another country argued against their being especially dangerous: "allowing a suspected international terrorist to leave our shores and depart to another country...., there to pursue his criminal designs, is hard to reconcile with a belief in his capacity to inflict serious injury to the people and interests of this country."181 Finally, allowing the detention of someone suspected of having "links" to a terrorist organization, "irrespective of its presenting a direct threat to public security in the United Kingdom and perhaps, therefore, of no relation to the emergency originally requiring the legislation" suggested the detention provisions were not a proportional response. ${ }^{182}$ The Lords

177. Id. [29].

178. Id.

179. Id. [31].

180. Id. [32]. The Lords referred to, among others, the high-profile case of Richard Reid, the socalled "Shoe Bomber," a British citizen who pleaded guilty in a Boston court to trying to detonate a bomb in his shoe on a flight from Paris to Miami. Fox Butterfield, Oaeda Man Pleads Guilty To Flying With Shoe Bomb, N.Y. TIMES, Oct. 5, 2002, at A11.

181. A v. Sec'y of State for the Home Dep't [2004] UKHL (Civ) 56, [33], 2005 All E.R. 169 (Eng.).

182. Id. [34]. 
further noted that the problem stemmed at least in part from "the choice of an immigration measure to address a security problem." "183 In short, trying to adapt existing legislation to combat a new problem resulted in more problems than it solved. The government would be better served by creating new legislation specifically tailored to the threat it faced.

In conclusion, the Lords "strongly recommend[ed]" that the legislation allowing "foreign nationals to be detained potentially indefinitely should be replaced as a matter of urgency." 184 Despite stating that legislation was outside the province of the courts, the Lords felt strongly enough to suggest potential revisions: "New legislation should: (a) deal with all terrorism, whatever its origin or the nationality of its suspected perpetrators; and (b) not require a derogation from the European Convention on Human Rights." 185

Following the Lords' decision, the government proposed new legislation abolishing the detention provisions of the ATCSA and replacing them with "control orders" to monitor the activities of terrorism suspects. ${ }^{186}$ Measures would range in severity from curfews, through electronic tagging, to indefinite house arrest. ${ }^{187}$ More importantly, the measures would apply equally to British citizens as well as noncitizens. ${ }^{188}$ The eight remaining detainees were released in March 2005 with control orders to be served on them all "including partial house arrest with a nighttime curfew, tagging and a ban on meeting anybody not approved by the home secretary." ${ }^{89}$ Control orders remain controversial, and the government already has delayed its decision on whether to renew the legislation-slated to expire in March 2006-until further study of their efficacy can be made. ${ }^{190}$

The July 2005 bombings in London also have prompted further legislation, with Tony Blair announcing that " $[t]$ he rules of the game are changing." 191 In place of indefinite detention, deportation now plays a key role, with the majority of those released from Belmarsh being forced

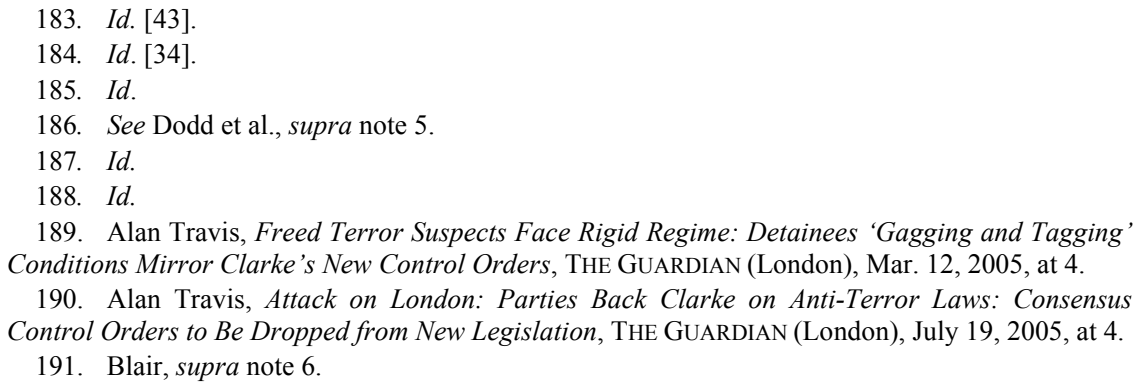


to leave the country. ${ }^{192}$ To counter concerns that such actions will result in those exact violations of the ECHR that the previous scheme of detentions were intended to prevent, the government sought "assurances" from the receiving countries that the deportees would not be tortured upon their return. ${ }^{193}$ Foreseeing probable legal challenges to such action, however, the government stated it was prepared to "legislate further, including, if necessary[,] amending the Human Rights Act."194 Future antiterrorism legislation would include a new offense of "condoning or glorifying terrorism." $" 195$

\section{ANALYSIS}

\section{A. The Case for Continuing Existing Procedure}

There are strong reasons behind the American and British governments' desires for strong legislation to deal with the threat of terror. The stakes are high in terrorist cases, as the attacks in New York and London demonstrated. The ordinary criminal law, often concerned with the punishment of offenses rather than their prevention, is singularly unsuited to stop terrorist acts before they occur. Moreover, the deterrent value of any such punishment is likely to be negligible, if any. Ordinary criminal law falls short for a number of reasons. First, rules of evidence are generally not suited to collecting information until after the crime has been committed. Further, what little evidence may exist before commission of the crime likely will take longer to amass, hence the need for longer detention periods. Second, when a country's military is fighting on the other side of the world, it does not have the luxury of providing individualized hearings to determine whether the people it has detained are likely to again attempt to kill them immediately upon release. Third, trials of such terror suspects may revolve around highly sensitive information, which may potentially endanger the military if revealed. With so much at stake, the argument goes, it is better to err on the side of caution: detain people first and determine their innocence later. This argument is bolstered by the temporary nature of most antiterror laws. For example, as described above, Lincoln was able to

192. Patrick Wintour et al., Judges to be Told to Act on Deportations: Government Risks Clash on Human Rights, THE GUARDIAN (London), Aug. 12, 2005, at 1.

193. Blair, supra note 6.

194. Id.

195. Id. 
suspend habeas relief and it was reintroduced as soon as the Civil War ended. ${ }^{196}$

Moreover, both countries have attempted to provide at least some procedural protection for their detainees. The U.S. government, acknowledging the holding in Hamdi, has granted many detainees access to Combatant Status Review Tribunals (CSRTs), conducted by military commission. ${ }^{197}$ Further, the Court in Hamdi indirectly suggested his detention was only justified so long as hostilities were ongoing in Afghanistan. ${ }^{198}$ Likewise, in the United Kingdom, people certified and detained as terrorists under the ATCSA had their certifications reviewed at regular intervals, albeit by a specially appointed secret court. ${ }^{199}$ In addition, the ATCSA's detention provisions had a built-in expiration date and were allowed to expire. ${ }^{200}$ Even before that, had either the government or the European Court of Human Rights decided that the period of "national emergency" justifying Britain's derogation from the ECHR had ended, the detentions would likewise have had to end. Previous similar derogations from the ECHR were declared valid by the European Court because of the presence of similar safeguards. ${ }^{201}$

\section{B. The Case for Rethinking Existing Procedure}

Many commentators and civil liberties groups despaired at the lack of real debate within each country's legislature before they passed the respective bills. Both were rushed through the legislatures in a matter of weeks, with no real chance for discussion or review, cobbled together from a series of new laws and amendments to existing statutes. ${ }^{202}$ Yet their impact was far reaching: in particular, the Joint Resolution's extraordinary breadth was used to justify the indefinite detention of hundreds without trial. At times of crisis, public anxiety is overwhelmingly high, and governments understandably feel that they must be seen doing something to allay the public concern. For example,

196. See supra notes 11-16 and accompanying text.

197. Adam Liptak, In First Rulings, Military Tribunals Uphold Detentions of 4, N.Y. Times, Aug. 14, 2004, at A11.

198. See supra note 58 and accompanying text.

199. See supra notes $156-63$ and accompanying text.

200. Anti-Terrorism, Crime and Security Act, 2001, c. 24, §§ 23, 29 (Eng.), available at http:// www.opsi.gov.uk/acts/acts2001/20010024.htm.

201. See Wattellier, supra note 128, at 407 ("The Court held the United Kingdom had not exceeded their margin of appreciation [in derogating under Article 15] because of the safeguards provided by the government." (citing Brannigan v. United Kingdom, 17 Eur. Ct. H.R. 539, 554 (1993))).

202. Thomas, supra note 141, at 1216-17. 
the Prevention of Terrorism (Temporary Provisions) Act 1974 was rushed through the British Parliament in a similar way following a series of pub bombings in Birmingham, England. ${ }^{203}$ As one Member of Parliament opined at the time:

"The justification for the Bill to my mind, is overwhelming, and I make no bones about the fact that I shall not listen with too much patience to any anxieties about whether this or that or the other civil right may temporarily be somewhat abridged .... The overwhelming mood in my constituency and I believe in my city, is one of vengeance.'

Legislation should not be developed through a feeling of "vengeance." Reprehensible though the actions are, feelings of revenge and destruction are likely to override competing concerns about civil rights in the heat of the moment.

Four years removed from the events of $9 / 11$, it is easier to cast a more critical eye at the legislation passed in response to the attacks. Notorious cases such as Hamdi may make it all the way to the Supreme Court, but there are less-reported cases that suggest a need for reform. Take, for example, the case of Purna Raj Bajracharya, arrested as a suspected terrorist in 2001 for accidentally videotaping a Federal Bureau of Investigations building in Queens, New York. ${ }^{205}$ The arresting officer decided within days that Bajracharya was only guilty of overstaying a tourist visa, but he was unable to prevent Bajracharya from being held in solitary confinement for three months until Bajracharya's eventual deportation. ${ }^{206}$ Rasul, in the case bearing his name, confessed in interrogation to meeting with bin Laden, but has since been released to Britain, along with three other detainees, after British intelligence verified that at the time the alleged meeting took place Rasul actually was working at an electronics store in the United Kingdom. ${ }^{207}$ It may be difficult to determine how effective the legislation is in preventing acts of terrorism, but it is easy to see the civil rights abuses it causes.

The civil rights abuses stem from a number of underlying problems in U.S. and U.K. law. First, neither country has satisfactorily defined "terrorist." The U.S. government has argued in applying the Detention

203. Id. at 1200 .

204. Id. (quoting Hansard, 882 PARL. DeB., H.C. (5th ser.) (1974) 648-50).

205. Nina Bernstein, In F.B.I., Innocent Detainee Found Unlikely Ally, N.Y. TIMES, June 30, 2004, at A1.

206. Id.

207. Vikram Dodd, Guantanamo Britons Sue Rumsfeld, THE GuARDIAN (London), Oct. 28, 2004, at 4 . 
Order that where it is "undisputed" that a detainee was captured in an active zone of combat, no further factual inquiry is necessary to justify his detention. ${ }^{208}$ This Detention Order could as easily result in the detention of aid workers and innocent civilians as those intent on destroying America, however. If the United States, as in Hamdi, applies a similar presumption to those detained by allied forces, such as the Northern Alliance, with an agenda of their own, the likelihood of innocents being wrongly detained is only exacerbated. Likewise, under the ATCSA, the definition of what constitutes "terrorism" is extraordinarily broad and may lead to the detainment of people not commonly understood to be terrorists. ${ }^{209}$ Following the July 2005 bombings in London, the Prime Minister stated that "[a]ctive engagement" with any of a list of "specific extremist websites, bookshops, centres, networks and particular organisations" would trigger deportation proceedings, without further defining "active" engagement. ${ }^{210}$

Second, detentions in both countries are indefinite. Under the ATCSA, foreign terror suspects were held until they could be deported to another country. The ECHR, of which Britain is a signatory member, forbids the deportation of people to countries where they will likely face death or torture, and few countries are likely to accept certified terrorists. Thus, the detainees faced indefinite detention, even if they were supposedly "free to leave" as the Home Secretary commented. Now they are just deported without being able to appeal until after removal from the country. Deportation can only serve as a quick fix, however, as it would leave any terrorist free to pursue his activities in another country, and further fails to solve the problem of citizen terrorists. Similarly, under the Joint Resolution, people such as Hamdi are held "for the duration of the conflict" without satisfactorily defining "the conflict." Such an amorphous concept as the War on Terror may conceivably never end, and detaining people for the duration may amount to a life sentence without trial.

Third, although the government now allows the Guantanamo detainees access to a CSRT, and the ATCSA has always provided for review of a detainee's certification as a terrorist, in neither instance does the detainee have access to a truly neutral decision maker to question his confinement. At least one district court already has found CSRTs to be

208. Hamdi v. Rumsfeld, 542 U.S. 507, 514 (2004).

209. See supra note 150 and accompanying text.

210. Blair, supra note 6. 
incompatible with military law, ${ }^{211}$ and under the ATCSA, the certification was reviewed at a secret trial that the detainee himself was unable to attend.

These concerns might seem less serious if British history did not belie the "temporary" nature of antiterrorist legislation. The EPA, for example, was designed to last for just two years, and instead Parliament renewed or extended it without question for twenty-seven years. ${ }^{212}$ There were three major reviews of the PTA in Britain between its implementation and 1991. All three started with the phrase "Accepting the continuing need for legislation against terrorism" and were tasked by people closely associated with the government. ${ }^{213}$ Such temporary legislation, intended to combat an emergency situation, has a habit of becoming the common state of affairs, which in turn affects the development of the regular criminal law. ${ }^{214}$ Likewise, papers released in the United States in January 2005 under the Freedom of Information Act reveal that the U.S. government had been contemplating terrorist threats much like the events of $9 / 11$ since the $1970 \mathrm{~s}$ - a time frame that further suggests the situation is anything but temporary. ${ }^{215}$

Like the EPA and the PTA before it, the ATCSA had a built-in expiration date. Like its predecessors, however, the Act likely would have been renewed by Parliament with little real discussion were it not for the Lords' recent ruling. Even now it is only the detention provisions that have been stricken, and the worryingly vague definition of terrorism remains.

Finally, there is the personal toll such detention puts on people detained under these laws. The case of G's nervous breakdown after two years in solitary confinement is far from unique. ${ }^{216}$ One author's study of the effects of the PTA on Irish detainees provides ample evidence of the effect just a few days' detention had upon the people detained. One interviewee stated,

211. Hamdan v. Rumsfeld, 344 F. Supp. 2d 152 (D.D.C. 2004).

212. Virginia Helen Henning, Anti-Terrorism, Crime and Security Act 2001: Has the United Kingdom Made a Valid Derogation From the European Convention on Human Rights?, 17 AM. U. INT'L L. REV. 1263, 1294 (2002).

213. HILlyARD, supra note 127 , at 8 .

214. “This is an example of an insidious circular process in which draconian laws soften us up for similar laws which become the desired standard for further measures."” Joe Sim \& Phillip A. Thomas, The Prevention of Terrorism Act: Normalising the Politics of Repression, 10 J.L. \& SoC'Y 71, 75 (1983) (quoting 38 PARL. DEB., H.C. (6th ser.) (1983) 633).

215. Nixon-Appointed Terror Panel Foresaw Risk Of Dirty Bomb, Airliner Attacks, THE FRONTRUNNER, Jan. 24, 2005.

216. See Gillan, supra note 168 and accompanying text. 
"I was stripped of my rights as a citizen. They can do what they like, tell you what they like. I felt I had no rights whatsoever. ... These people don't believe you are telling the truth, even if you are telling the truth; they just don't believe you. As far as they are concerned, you are a terrorist, you are a 100 per cent terrorist." ${ }^{, 217}$

The cost to innocent people wrongly detained in terms of their physical and mental well-being and the effects on their family and friends - not to mention their employment and finances-is documented on a disturbingly regular basis. Since those captured in Afghanistan were first brought to Guantanamo, there have been thirty-four reported suicide attempts by the detainees, culminating in ten simultaneous attempts on a single day in 2003. ${ }^{218}$

The other major concern is the erosion of faith in the workings of justice that unjustified detentions cause. Where the law is undecided and conflicting, it may be perceived as arbitrary and capricious. The problems this may cause for a country such as the United States, which holds itself up as a prime example of democracy at work, should be apparent.

While it is easy to list the numerous ways in which antiterrorism legislation impinges on civil liberties with disturbing results, it is not so easy to see the ways in which it may already have prevented further acts of terrorism. It is likely that many of those held at Guantanamo did indeed fight against the United States, rather than serve as innocent aid workers, as many of them claimed. The law as it stood in 2001 was unable to prevent the attacks on the World Trade Center, but it is impossible to gauge whether the Joint Resolution or other legislation, such as the USA PATRIOT Act, will do any better. "[E]ach new attack tends to raise a presumption of ineffectiveness in relation to existing and earlier measures of legal control (how else to explain [the attack's] occurrence?)." 219 Perhaps it is time to admit that the situation is too ongoing to be characterized as an "emergency" and that any "temporary" abrogation of our civil rights is in fact going to be ongoing. As such, antiterrorism legislation needs to be refined and debated now by Congress when competing interests can fairly be balanced, rather than in the immediate aftermath of a terrorist attack when feelings run high and the country calls out for "vengeance."

217. HiLlyARD, supra note 127, at 251.

218. Detainees Sought Suicides en Masse: Guantanamo Jail Attempts Revealed, CHI. TRIB., Jan. 25,2005 , at $\mathrm{C} 1$.

219. Christopher Harding, International Terrorism: The British Response, 2002 SING. J. LEGAL STUD. 16, 17 (2002). 
The holding handed down by the Supreme Court in Hamdi is a good one. The government does need to be able to detain people in certain circumstances that the ordinary criminal law does not allow. To hold such people for several years without charge, however, and without the ability to challenge their detentions is unreasonable. Procedural safeguards are needed to ensure such detentions do not happen in the future. It should not be left to the courts to influence the development of the law in a case-by-case, and often contradictory, manner. Making laws is the province of the legislature, which can provide a more coherent and legitimate body of law. Laws also can be created afresh to deal with the new and unique threat that international terrorism in the twenty-first century presents. The following section suggests minimum reforms needed to balance the competing needs of individual rights and national security.

\section{Toward Balancing Detainee Rights}

Both the Joint Resolution and the ATCSA give the executive wide latitude in determining who may be detained as a terrorist. ${ }^{220}$ A tighter definition of terrorism is needed if the standard is not to be so broad that it encompasses acts that would normally be contained within the rubric of the regular criminal law. Otherwise, innocent people may be certified as terrorists and unscrupulous prosecutors given the incentive to read the definition broadly in an attempt at an end-run around the regular criminal law.

As a starting point, The American Heritage Dictionary gives a better definition of "terrorism": "The unlawful use or threatened use of force or violence by a person or an organized group against people or property with the intention of intimidating or coercing societies or governments, often for ideological or political reasons." ${ }^{221}$ Moreover, the ATCSA's loose definition of "having links to" a terrorist organization must be defined more tightly than just "supporting" it. Morally reprehensible though it may be, we cannot imprison someone just for sympathizing with bin Laden. "Providing material assistance or support" would help meet that threshold, with the courts able to decide what constitutes "material support" in a given case. "Active" engagement with proscribed Web sites and bookstores needs also to be defined carefully

220. See supra notes $28,149-50$ and accompanying text.

221. The American Heritage Dictionary OF the English Language (4th ed. 2000). 
so the noncitizen student writing a paper on religious extremism, for example, does not get labeled a terrorist and deported.

Congress must decide when and how to apply the threshold distinction between charging someone as a terrorist in a criminal courtin which case criminal procedure should be adapted to dictate how long a person can be held without charge - and holding someone for the duration of a war to prevent him from rejoining the enemy, in which case the detainee still needs the ability to meaningfully challenge his classification as an enemy combatant. ${ }^{222}$ The government simply cannot refuse to either try a detainee as a terrorist or unilaterally declare the detainee an enemy combatant, and attempt to hold him indefinitely in a legal vacuum until the courts force a policy change - particularly if the government's response to the court's decision is simply to find some way to subvert it and continue to hold the detainee pending the next adverse decision. Previous cases relied on by the government, such as Quirin, involved petitioners who freely admitted they were hostile to the United States, and so could be held for the duration of the conflict and possibly tried by military commission for war crimes. Few of the Guantanamo detainees have made such admissions, and the President's classification needs to be scrutinized by a court when the basis of their detention is disputed.

Regardless of whether the detainees are to be tried as criminals or simply held as enemy combatants, there needs to be a threshold level of evidence met before a person can even be detained on suspicion of terrorism. The danger of inaction is indeed great, so the "probable cause" standard is too demanding, and should be replaced with the lower "reasonable suspicion" standard so as to err on the side of caution. ${ }^{223}$ Furthermore, as stated in Hamdi, ${ }^{224}$ presumptions may operate in the government's favor, such as against a person intercepted in the vicinity of a foreign battlefield carrying a weapon. The mere presence of a person in the area alone, however, should be insufficient given the strong

222. A full discussion of the scope of the laws of war and why Al Qaeda members do or do not merit POW protections is beyond the scope of this Article. For a fuller discussion of the international rule of law and the rules of warfare, see Lieutenant Colonel (s) Joseph P. "Dutch" Bialke, Al-Qaeda \& Taliban Unlawful Combatant Detainees, Unlawful Belligerency, and the International Laws of Armed Conflict, 55 A.F.L. REV. 1 (2004).

223. For a fuller discussion of what constitutes "reasonable suspicion" see, e.g., David S. Rudstein, White on White: Anonymous Tips, Reasonable Suspicion, and the Constitution, 79 KY. L.J. 661 (1991); Loralyn Eckelberg Clark, Comment, Criminal Procedure-Is "Reasonable Suspicion" Becoming "Probable Cause”?, 69 N. D. L. REV. 999 (1993); Chris K. Visser, Comment, Without a Warrant, Probable Cause, or Reasonable Suspicion: Is There any Meaning to the Fourth Amendment While Driving a Car?, 35 Hous. L. REV. 1683 (1999).

224. See supra note 69 and accompanying text. 
possibility of detaining innocent civilians and aid workers. Military personnel cannot be recalled from fighting around the globe to give such evidence, so a brief affidavit would suffice.

As with the warrant requirement, whether a prima facie case of terrorism exists is a decision that should be made by a neutral decision maker. The Executive may be the best informed, but it can hardly be considered neutral when it consists of politicians, such as the Home Secretary, heavily invested in the War on Terror, often with their careers dependent in part on the number of terrorists they are seen to capture. Moreover, if certified rather than captured on a battlefield, the certification should be reviewed at regular intervals by a similarly neutral decisionmaker, and not by the person issuing the certification in the first place.

The value of many of the detainees at Guantanamo has been their intelligence value, rather than the suspicion that they are involved in an imminent attack. Once captured, however, there should be a limit on how long the detainee can be interrogated before access to a lawyer is granted. Because critical intelligence may be gained from a suspect before a lawyer is appointed or the suspect is apprised of his rights, a delay longer than that granted in regular criminal law may be appropriate, but the delay should be measured in days rather than weeks. ${ }^{225}$ Information gleaned during this time could then be used to apprehend other terrorists, or even prevent attacks, but it should not be admissible at trial or in front of a military commission against the detainee unless he knowingly waived this right. The detainee should not have to wait several years in confinement while his habeas petition is heard, overturned, appealed, and reversed by various courts. To prevent a recurrence of Padilla, the place to bring a habeas petition contesting detentions as either a terror suspect or enemy combatant should clearly be prescribed by statute. The Supreme Court declared it to be the "immediate custodian" in Padilla, ${ }^{226}$ but this may lead to future cases in which detainees are unable to bring habeas petitions because the immediate custodian is a foreign national running an American prison abroad. Thus, the statute should be amended to allow the Secretary of

225. Turkey, for example, has set the outer limit at four days, so that any signs of physical mistreatment by the captors will still be visible to the arraigning judge. See Report of the Joseph R. Crowley Program/Lawyers Committee for Human Rights: Joint 1998 Mission to Turkey, Special Report, Justice on Trial: State Security Courts, Police Impunity, and the Intimidation of Human Rights Defenders in Turkey, 22 FORDHAM INT'L L.J. 2129, 2153 (1999).

226. See supra note 104 and accompanying text. 
Defense to be a named recipient where the Defense Department is ultimately responsible for the detention.

At any arraignment, military commission, or habeas hearing, the charges against the detainee should be explained in a manner sufficient for the detainee to understand the case against him and afford him a meaningful opportunity to formulate a defense. The detainee should also be appointed a lawyer. The average American would have little chance of successfully negotiating his way through a case against him-a foreign detainee with limited English ability and no knowledge of the American legal system would find doing so nearly impossible. The detainee should then be afforded regular access to the lawyer, but, for security purposes, this access need not be unmonitored. ${ }^{227}$ To prevent the added burden, cost, and security risks of transporting a detainee from a foreign prison to a domestic court, such access to a tribunal could be by way of video conference. Moreover, as mentioned above, it is unrealistic to expect military personnel to appear for cross examination by the detainee, even by video conference, so the right to cross examination must be similarly limited.

If the suspect is to be tried in the criminal system, there is no reason why the trial cannot continue at a pace similar to that in regular criminal trials, with some modifications. Indeed, before 9/11, all terrorism cases in the United States were tried in federal court, ${ }^{228}$ and the government has chosen to try some of the easier terrorist cases since $9 / 11$ in federal court. $^{229}$ Treating terrorism as a crime rather than a war also allows the United States to retain the moral high ground in the fight against terrorism: They may attack us, but we do not reciprocate with arbitrary bombing campaigns, perhaps killing innocents. We "bring them in alive," convict them fairly, and show the rest of the world the principles of justice at work. Moreover, this method attaches greater moral condemnation to the acts of terrorism: crimes are carried out by criminals; wars by warriors.

As with the regular criminal law, the right to appeal should also be given as a matter of right to every defendant. By standardizing the law

227. The Bureau of Prisons, for example, already has a system in place for monitoring attorneyclient contact where "there is a substantial risk that a prisoner's communications or contacts with persons could result in death or serious bodily injury to persons, or substantial damage to property that would entail the risk of death or serious bodily injury to persons." 28 C.F.R. $\S 501.3$ (a) (2005).

228. For example, in United States v. Salameh, 54 F. Supp. 2d 236 (S.D.N.Y. 1999), the trial of the 1993 bombers of the World Trade Center led to their conviction in regular criminal court.

229. John Walker Lindh, the so-called "American Taliban," and Richard Reid, the "Shoe Bomber," have both been convicted this way. Butterfield, supra note 180; Neil A. Lewis, Lindh Plea Deal, N.Y. TiMES, July 21, 2002, at 2. 
regarding the detention and trial of terrorism suspects, far fewer appeals will be sustained. Further, the law would achieve more consistency by avoiding the decision-prompted flurry of filings and governmental responses meant to delay the day of reckoning. Moreover, by reducing litigation posturing the legislation would reduce the time the detainees languish in indefinite confinement.

Finally, as Rasul shows, the law should not distinguish between citizens and noncitizens insofar as both should have the ability to bring a habeas petition. ${ }^{230}$ If detainees are confined by U.S. forces they should not be prevented from challenging their detentions on the sole ground that they themselves are not American or are not detained on American soil and, as such, have no constitutional rights. The decision in Rasul is a good one, although sadly capable of being read too narrowly to deny noncitizen detainees further meaningful access to the courts. ${ }^{231}$ It seems improbable that the Supreme Court would hold that noncitizens are allowed to bring actions challenging their detentions in federal court, while intending that the courts be unable to hear them. Moreover, as $A v$. Secretary of State for the Home Department demonstrates above, when a law discriminates between terror detainees on the basis of nationality, it holds the law up to charges of discrimination which may well lead to its being overturned and potentially genuine terrorists walking free. ${ }^{232}$ It also prevents the government from detaining genuine terrorists where they happen to be citizens. Nationality may be pertinent to the issue of immigration and defining the full spectrum of detainees' rights, but the right to appeal detentions without charge by the Executive should not be one of them.

\section{CONCLUSION}

Given that the War on Terror is likely to be an ongoing, nearpermanent state of affairs - at least for the foreseeable futuretemporary, "emergency" legislation, created hurriedly at a time of heightened national emergency is unsuited to maintaining the delicate balance between national security interests and human rights. The present state of the law allows for the indefinite detention of people who may or may not be terrorists with no ability to challenge their detentions, and a steady trickle of releases ordered by the courts on a case-by-case

230. See supra note 85 and accompanying text.

231. See supra note 86 and accompanying text.

232. See supra notes $179-85$ and accompanying text. 
basis. Instead we need a new framework of custom-made legislation, created in a time of relative calm, to combat the unique realities of twenty-first century international terrorism. While a sweeping overhaul of antiterrorism legislation is beyond the scope of this Article, at a minimum, new legislation needs to (1) be permanent; (2) allow terror suspects the meaningful opportunity to challenge their detentions or certifications in front of a neutral decision maker; and (3) be applied equally to citizen and noncitizen alike. Then national security interests will not be compromised unduly, and individual human rights will not be trampled. 